\section{Cardiovascular Biomarkers}

Pathophysiology and Disease Management The Humana Press 999 Riverview Drive, Suite 208, Totowa, New Jersey 07512, USA Edited by: David A. Morrow, MD

Brigham and Women's Hospital, Boston, MA Publ. Date: 04/27/2006

640 pages Contemporary Cardiology ${ }^{\mathrm{TM}} 7 \times 10$

ISBN: Hardcover 1-58829-526-5 \$175.00£ 107.00 Full Text 1-59745-051-0 \$175.00

Microchip Capillary Electrophoresis,

Methods and Protocols

The Humana Press, 999 Riverview Drive, Suite 208, Totowa, New Jersey 07512, USA

Edited by: Charles S. Henry

Colorado State University, Fort Collins, CO

Publ. Date: 03/01/2006

248 pages Methods in Molecular Biology ${ }^{\text {TM }} 3396 \times 9$

ISBN: Hardcover 1-58829-293-2 \$ $89.50 £ 55.00$

Full Text 1-59745-076-6 \$89.50
Diagnostic Bacteriology Protocols, Second Edition The Humana Press, 999 Riverview Drive, Suite 208, Totowa, New Jersey 07512, USA

Edited by: Louise O'Connor, PhD

National Diagnostic Centre, National University

of Ireland, Galway, Ireland

Publ. Date: 04/26/2006

236 pages Methods in Molecular Biology ${ }^{\text {TM }} 3456 \times 9$

ISBN: Hardcover 1-58829-594-X \$99.50£ 61.00

Full Text 1-59745-0143-6 \$99.50 